\title{
Trading in freedom: rethinking conspicuous consumption in post-apartheid political economy
}

\author{
Ulrike Kistner \\ Ulrike Kistner is Professor at the Department of Philosophy at the University of \\ Pretoria. ukistner@iafrica.com
}

\begin{abstract}
This article investigates some accounts of conspicuous consumption in South Africa, tracing their variously linear, circular and disjunctive paths, identifying and explaining some methodological impasses, and concluding with reflections on the interrelation between distinct armatures of value and exchange. The first kind of trajectory that impinges in looking at accounts of conspicuous consumption post-apartheid is a linear one, indicating the direction 'up from' and 'out of' racially based discrimination and oppression structuring sumptuary regulations. With regard to this trajectory, I will show that this is not as linear as it may initially appear, proceeding from apartheid to its 'post-', but that it is indicated both in the liberation movement's programmatics and in the aspirationalism mobilised by advertising and marketing strategies at an earlier stage. In considering the association of freedom with de-regulated consumption, a circularity emerges, in relation to which I would like to posit, for purposes of critical analysis, distinct forms of exchange implicit in the contexts described for the emergence of a new 'middle class' at a specific conjuncture, to then spell out some of their complex interrelations and dynamics.
\end{abstract}

Keywords: conspicuous consumption, equivalence, social distinction, social stratification, sumptuary regulation, tournaments of value

\section{Consuming society}

Registered among the visible changes in the social physiognomy of South Africa post-apartheid is the emergence of a stratum of politically connected entrepreneurs 
displaying their newly acquired status through demonstrative consumption (see Seekings and Nattrass 2006: 308; also Posel 2010: 158). This development appears all the more conspicuous as it is highlighted, in stark contrast, against more generalised poverty and deepening inequality (see Seekings and Nattrass 2006: 368; also Leibbrandt et al. 2010: 32; Seekings 2011: 22).

This article sets out to trace the social meanings, moral claims and political figurations of consumption in post-apartheid South Africa, critically inflecting some of the explanations by scholars and exhortations by politicians.

The rise and economic-political power of the new upper-middle stratum is accounted for sociologically by reference to the statutory deracialisation of the economy enshrined in the Black Economic Empowerment (BEE) Act, 2003, and in Affirmative Action policies, and the corresponding quota regulations in the private and the public sectors (see Bezuidenhout et al. 2008: 6). 'Transformation' in these sectors has become virtually synonymous, for some analysts, with the 'selfenrichment of a small stratum of entrepreneurs benefitting parasitically' (Nzimande 2006) from brokering tenders and contracts, procurement and licensing deals in the private and public sectors. Depending on state contracts for the accumulation of assets, the 'empowerment elite' remains 'economically weak and politically dependent on the ANC' (Plaut and Holden 2012: 213-238).

Yet the pace and embrace of upward social mobility on the part of this entrepreneurship seem to have surpassed the expectations of some of its ushers and gate-keepers. Interpreting accumulation in fundamentally moral terms, the latter now urge moral restraint. Towards the end of his presidency, which had inaugurated the '1996 class project', Thabo Mbeki castigated South Africans for having lost their moral compass:

It is perfectly obvious that many in our society, having absorbed the value system of the capitalist market, have come to the conclusion that for them, personal success and fulfilment meant personal enrichment at all costs, and the most theatrical and striking public display of that wealth.

The meaning of freedom has come to be defined, not by the seemingly ethereal and therefore intangible gift of liberty, but by the designer labels on the clothes we wear, the cars we drive, the spaciousness of our houses and our yards ... (Mbeki 2006)

Calls for moral restraint, for a renunciation of acquisitiveness and for valuereorientation are being ritualistically repeated by some of the same persons in government positions who have variously been accused of corruption and/or lavish spending at taxpayers' expense.

A case in point is the formation of the Economic Freedom Fighters (EFF) as a political party, launched on 13 October 2013 in the informal settlement of Nkaneng at the foot of the 'koppie' where 34 people, mostly striking miners, were killed 
by police in August 2012. While their 'Commander-in-Chief' Julius Malema is facing charges of fraud, corruption, money-laundering and racketeering, the EFF proclaimed that 'political power without economic emancipation is meaningless', explaining that

[t]he movement is inspired by ideals that promote the practice of organic forms of political leadership, which appreciate that political leadership at whatever level is service, not an opportunity for self-enrichment and self-gratification. (http://effighters. org.za/about-us/)

Calls for the introduction of checks and balances into the financial management of organisations, institutions and political parties have been supplemented with calls for lifestyle audits of prominent figures within the Tripartite Alliance, initially by the Congress of South African Trade Unions (Cosatu), then by the South African Democratic Teachers' Union (Sadtu), and more recently by the civil society initiative 'Awethu!', to control 'the continuing feeding frenzy for tenders and concessions as the parasitic black bourgeoisie continues its strategy of buying political influence to build personal fortunes' (IOL News, 20 February 2010).

The high moral tone of austere warnings, in turn, provides rich pickings for its polemical denouncement, such as the retort by entertainment and mining magnate, Kenny Kunene, touted by the media as the 'King of Bling', to Cosatu's former General Secretary, Zwelenzima Vavi. In an open letter published under the heading 'I'll spend what I like', Kunene (2011) challenges his opponent's moralising condemnation of 'bling', upholding his own means and choices of expenditure as 'honest achievement'. In his flamboyant speech-acting, the condemnations of conspicuous spending and consuming themselves become elements in tournaments of value. ${ }^{1}$

The apparent intractability of what has been ritually, moralistically, sociallycritically, and politically-programmatically decried as a societal problem calls for further probing - discursive, methodological, historical-critical - on which I embark in this article. In particular, I would like to follow investigations into the phenomenon of conspicuous consumption, tracing their variously linear, circular and disjunctive paths, identifying and explaining some methodological impasses, and concluding with reflections on the interrelation between distinct armatures of value and exchange.

\section{General equivalence and social distinction}

The first kind of trajectory that emerges from a study of accounts of conspicuous consumption post-apartheid is a linear one, indicating the direction 'up from' and 'out of' the racially based discrimination and oppression structuring sumptuary regulations. In general terms, this observation is borne out by the libidinal-economic- 
anthropological consideration that legally codified racial divisions have structurally thwarted the relation between the wish and a field of action for black South Africans, whereas the money form, as general equivalent, formally and indeterminately provides the possibility of a relation between the wish and a field of actions toward its fulfilment. The socio-logically equivalential form of money, which it attains under generalised commodity exchange, entails that relations mediated by money can be projected backwards and forwards historically. Thus, the trajectory figured as consumer liberation from a racial order is not historically as clearly bounded and defined as it may initially appear, proceeding from apartheid to its 'post-'. Long before the end of apartheid, it manifests itself in both the liberation movement's programmatics and in the aspirationalism that advertising and marketing strategies shaped and tapped into. But in either case, to the extent that the decoding of a racial order is considered in terms of deregulated consumption (rather than as a political project), a circularity emerges, which pervades explanations of conspicuous consumption charting the relationship between symbolisations of race and representations of commodities. While granting them some explanatory purchase, I would want to point to their limits. At their limits, a critical task imposes itself, in outlining a circulatory difference between non-equivalent and equivalential forms of exchange implicit in the contexts of social stratification that have spawned what has variously been termed a new 'middle class' 2 at a specific conjuncture. However, to make these forms of exchange salient for critical analysis would mean having to consider their dynamics beyond static and binary-oppositional typologies of forms of exchange, and beyond their role as functionalist socio-economic descriptors, just as the forms of conspicuous consumption described for post-apartheid South Africa defy economic rationality.

The perplexities posed by contemporary observations of conspicuous consumption, indexed to the deregulation of racialised consumption, partly arise from the blind spots that have opened up in the conceptualisations of 'race' tethered to class, through which racial capitalism in South Africa has been understood in the ANC-SACP Alliance's programmatics since the early 1960s. ${ }^{3}$ The notion of 'class' in the national liberationist tradition, gaining (if often contested) impetus from independent trade unionism in the 1970s and 1980s, was referenced to a Marxian critique of political economy, foregrounding aspects of capital accumulation and racially differentiated categories of industrial labour, in tandem with the making, the role, and the agency of the working class, particularly urban-based workers in the mining, steel, metal and chemical industries, and motor manufacturing. 'Class analysis' moved between categories of class structure, ownership of the means of production, class conflict, class consciousness, economic interest and power, labour process and the organisation of production, the production and extraction of surplus value, capital accumulation and exploitation. 
This understanding of 'class' eclipsed other characterisations of South African social formations of the 1950s and 1960s (see Seekings 2008: 23), which had foregrounded criteria of status, honour and prestige, and lifestyle orientations in the study of the middle class as stratum within a plurality of conceptual frameworks (principal among them Max Weber's chapter on 'Class, status, party' ([1922]1978)), focusing on (occupational) stratification, differentiation and distinction. Of particular interest to sociologists and political analysts at the time was the emerging 'African middle class', economically and politically constrained, subordinated or excluded by apartheid laws and racial discrimination, and socially differentiated from the working class. Liberal political analysts invested this stratum, driven to radical opposition, with hopes for political leadership and change (Seekings 2008: 11).

'Race relations' sociologist, Leo Kuper (1965), viewed 'class' in terms of occupation, status (marked by educational level and 'culture'), prestige and distinction (manifest in residential area, distinctive interiors, auto-mobility, personal appearance, recreational and social activities) and lifestyle (displayed in conspicuous consumption). ${ }^{4}$ Was this 'African middle class', he asked,

'simply an occupational classification, conveying no more than certain objective differences implicit in the occupational structure', or were there 'social correlates to this occupational classification' such as 'a distinctive style of life, with special patterns of association and claims to prestige made manifest in conspicuous consumption'? (Kuper in Seekings 2008: 14)

It is as if recent investigations of conspicuous consumption in post-apartheid South Africa are taking up this challenge, implicitly presenting a rejoinder to earlier, largely forgotten or ignored accounts of social stratification, and providing them with a telos. Based on her observations on black consumers bursting onto the scene in post-apartheid South Africa, and on the conspicuous display of their aspirations and acquisitions - which have attained not only social distinction but also political effect - Deborah Posel (2010: 173) speaks of 'the emancipatory significance of black acquisition'. She traces the close relationship that she posits between political emancipation and conspicuous consumption to the history of racially based regulation of consumption in apartheid South Africa, stating that 'if blackness was produced as in part a restricted regime of consumption, the politics of enrichment could readily adopt the discourse and symbolism of emancipation' (ibid.).

This near-axiomatic statement has set the direction for Posel's article on conspicuous consumption and race, and for the burgeoning research productivity in that field in recent years. Rather than reading it in terms of the material implication in which it is formulated, I would like to pause to disentangle this statement. A change of register is indicated in the statement: the first part refers to racially coded sumptuary regulation which is instrumental to social differentiation on the basis of 
distinction (indicated in the work of Weber and Thorstein Veblen), while the 'politics of enrichment' couched in terms of emancipation of the second part of the statement is predicated on commodity fetishism arising on the back of the general equivalence of money (indicated in the work of Karl Marx and Georg Simmel). The contradictory relationship between these two armatures - distinction and equivalence/equalisation - provides a critical juncture for the reflections to follow.

Posel implicitly references Veblen's notion of 'conspicuous consumption' (1899) and sociological studies on post-slavery consumption patterns and popular culture in the United States (US) (see Gilroy 2010), while explicitly citing the example of the rise of tycoon Richard Maponya outwitting apartheid strictures to triumph upon 'liberation', to rich effect in post-apartheid township consumer culture.

Regulation of consumption, Veblen suggests, is a way of creating and maintaining social distinctions. The leisured classes have historically indulged in unproductive consumption, while imposing on the labouring classes a consumption regime restricted to bare necessities. Luxury and comfort, particular foodstuffs and especially alcoholic drinks, were reserved for the leisured classes and considered taboo for the labouring classes. The consumption of necessities does not generate any notion of merit or prestige, except in contradistinction to those occupying the lowest ranks of the social order, whose subsistence is precarious (Veblen [1899]1915: 96-97).

Figured within this general picture, racially divided South African society did not, until the latter stages of apartheid rule, constitute an exception. The spectra of available consumer goods on offer in the food, clothing, furniture and appliance retail trade were differentiated according to social and racial categories, especially in the countryside, in villages and small towns. During the 1950s, for instance, black customers did not, as a rule, have ready access to 'European liquor', white bread and white sugar - these being items symbolically charged in contexts of regulated consumption (see Appadurai 1986: 39). Retail in townships, likewise, was limited, with respect to both the size of the enterprise - with the 'one-man-onebusiness' policy prior to 1976 - and the range of commodities on offer. As far as the Bantu Affairs Committee was concerned, businesses in townships had to 'confine themselves to the provision of the daily essential necessities of the Bantu' (Secretary for Bantu Administration and Development, 14 February 1963, in Mager 2007: 89).

Even where racial discrimination was not officially and openly practised, a well-attired black South African was considered 'out of place' in sites of 'white consumption' - in shopping malls, restaurants, pubs, as well as in pleasure, leisure and holiday resorts.

Sumptuary regulations pertaining to liquor, in particular, went through numerous debates and policies, between prohibition and control. The Native Urban Areas Act, 1923, and the subsequent Liquor Act, 1928, with its numerous amendments in the 1930s and 1950s, which sought to place tight restrictions on liquor brewing, 
consumption and trade, were found to have been less than effective, fostering illicit liquor dealing and enriching black entrepreneurs (Minister of Justice, House of Assembly [South Africa], Debates, 16 June 1961, in Mager 2007: 88). In the 1960s, parliamentary debates devoted renewed attention to the 'native liquor problem'. The regulatory lobby won out against the prohibitionists, with the former arguing that 'the privilege of European liquor' would be misconstrued by 'an immature people' as marker of 'an elevated status' (see Mager 2007: 88). The lifting of the ban on the sale of 'European liquor' to Africans was accompanied by a ban on shebeens and the trade of liquor other than through outlets alongside beer-halls, administered by the Bantu Areas Administration Boards in the townships; sales revenues from the liquor trade were used to finance the limited infrastructure of the townships. (Thus, it is no coincidence that the protest actions of students in 1976 also targeted beer-halls and other liquor outlets in the townships.)

Considering the recent history of the racially discriminatory regulation of consumption, the legendary success story of Richard Maponya is hardly surprising. Nor is it surprising that he is being celebrated locally as the hero of the consumer liberation struggle. He recounts that ever since the 1950s, he had explored every gap and loophole of apartheid town planning and municipal regulations in his endeavour to open Soweto for trade and business. Looking back, he remembers that aspiration to even limited luxury on the part of black South Africans was considered an inadmissible transgression of lines firmly laid down. 'If you had a licence to trade, you were even restricted to the goods you could sell. You were expected to sell necessities, such as sugar, maize, bread and rice. If you were found selling asparagus, you were punished as it was called a luxury' (Hlengani in Posel 2010: 170; see also Maponya 2010).

Interesting about Maponya's political-consumption autobiography is its sequencing: from what he calls 'humble beginnings' in dairy products to general dealerships including greengroceries, butcheries and food outlets - the latter being the 'playground of political leaders', which came with social, symbolic and 'political' capital. These food outlets are mentioned with a hint at transgression of the sumptuary laws prohibiting the consumption of luxury food items. This stance of sumptuary disobedience freed the demand for luxury goods from the authority of political regulation, and initiated - in terms of symbolic legitimacy initially - the 'free play' of individual tastes and styles, spurring the production and consumption of second- and third-order luxury goods (see Appadurai 1986: 38-39). The next step in Maponya's career is consistent with this consideration: the General Dealer, he tells his audience, expanded and diversified to include bottle stores - in violation of the alcohol regulations imposed on townships - and supermarkets. Distinctly 'not for the natives' was the attempt to open a filling station, which came later; the step from there to a motor car franchise seemed a consistent one. A luxury motor vehicle 
franchise in Soweto once again pushed boundaries, and involvement in private transport operations followed. Further ventures were, in sequence, horse racing, cold drinks, and cell phone service provision (Maponya 2010).

This sequence traces a trajectory of decodings redrawing the lines of social distinction, each punctuated by particular objects of consumption signifying specific lifestyle orientations and decisions: luxury - i.e., decidedly non-essential - food and drink items (the Uncle-Tomistic American translation of Fanon, 'sho good eatin', comes to mind; see Gilroy 2010: 12); and vehicles signifying freedom of movement, and movement individually initiated and embarked upon, bypassing segregated transport, transport boycotts and violence along transport routes, and giving meaning to 'auto-mobility' (the role of the private car, with its dizzying freedoms, in the American civil rights struggle comes to mind; see Gilroy 2010: 12). Vehicle sales, in turn, were rarefied later, once cars had conquered mass markets, by luxury trimmings and niche markets.

These socio-political and commercial processes in the passage out of poverty and towards citizenship (see Gilroy 2010: 9) would lead us to revisit the gap or opposition that political and cultural-critical discourses have insistently inserted between them. While 'the politics of enrichment could readily adopt the discourse and symbolism of emancipation' (Posel 2010: 173), the political and cultural-critical discourses themselves have not been inert in the mutual assimilation of the sociopolitical and commercial processes concerned.

Positively treating the state as capital resource, and as agency, through BEE legislation, brokering deals and securing tenders in the state and private sectors, is not inconsistent with the goal of liberation enshrined in party programmes and congress resolutions in the course of the 'national democratic revolution', of 'seizing state power' and 'gaining state control'. This aim is clearly formulated in an ANC discussion paper entitled 'The state, property relations and social transformation' (1998):

In a systematic way, the NDR [National Democratic Revolution] has to ensure that ownership of private capital at all $[\ldots]$ levels $[\ldots]$ is not defined in racial terms. Thus the new state - in its procurement policy, its programme of restructuring state assets, utilisation of instruments of empowerment, pressure and other measures - promotes the emergence of a black capitalist class.

A more recent re-assessment of the state of the NDR holds that

[t]he black petit-bourgeoisie and the black middle class, due to the nature of apartheid capitalism which excluded them from the economic main stream, are the motive forces [understood as 'drivers of change'] of the NDR ....

At the same time, it assures these 'drivers of change' that 
[socialism] is not a society where private non-exploitative property (such as houses, cars, clothes) will be commonly shared.

Socialism is about ending the private ownership of the means of production (mines, huge farms, monopoly industries).

Socialism does not do away with personal property. Socialism does away with private property - property owned by individuals and used to make a profit such as factories and banks. People will be able to have and cultivate personal property items like cars, TVs and ipods. (ANCYL 2009)

The entanglement of cultural-political and commercial indicators of personal freedom is not a new phenomenon peculiar to post-apartheid South Africa. It is implicated from the outset in generalised commodity exchange mediated by money. Formal equality in spheres of retail and consumption was not as unimaginable as ideologues of segregation and apartheid tried to make it out to be in spatial planning, in the domains of political participation and social interaction. The marketing of particular products proceeded along different routes relatively early on. ${ }^{5}$

Racialised patterns of consumption are not directly linked and limited to the apartheid period, as Posel's study would suggest, but arise from modes of statusseeking in relation to particular reference groups more generally. In a study on 'Conspicuous consumption and race' conducted in the US between 1986 and 2002, three researchers from the universities of Chicago and Pennsylvania found 'that Black and Hispanics consume 29 percent and 25 percent more visible goods than Whites with similar permanent income' (Charles et al. 2007: 12). The correlation of race and class with regard to conspicuous consumption is indicated in the finding that blacks and Hispanics of a particular age and income group expend the highest proportion of income on items of conspicuous consumption, while this expenditure level is found to decrease with increasing age and mean income levels of reference groups. Increased spending on visible goods, the data indicate, leaves fewer resources to spend on education, healthcare, food and housing, recreation and cultural pursuits (ibid: 32 ).

Replicating the signalling model of status in the first decade of the $21^{\text {st }}$ century in socio-economically more unequal South African society, Wolfhard Kaus (2010: 3) obtains similar results, but with a higher percentage of expenditure on items of visible consumption: 'Coloured and Black households, whose mean income is much less than that of white households, are found to spend on average about 35 to 50 percent more on visible consumption than comparable White households', which is being read to suggest that white South Africans have different or more differentiated signalling channels at their disposal (ibid: 15). This finding is echoed by individual researchers who participated in the so-called 'Black Diamond' studies: 'Generally speaking, the black middle class is certainly more indebted than its white 
counterpart. What we've found is that many black consumers are mortgaging a lifestyle they simply ... cannot afford ... [as] there appears to be a greater need for conspicuous consumption among black consumers in order to "show that they've arrived"' (Mateboge in Krige 2009: 11).

However, there are good reasons to treat these approaches with a considerable dose of scepticism. The same move that gives credibility to the phenomenon of conspicuous consumption as justified and creative response to the racialised regulation of consumption, and its deregulation, relegates this response itself to commodity culture. To illustrate the circular movement in this argument, let me retrace its steps: emancipatory aspirations found their expression in the desire for, or acquisition of, particular goods and self-stylisations that had, in their advertising and marketing, already been coded in terms referring to race and class, while reaching beyond them.

The marketing surveys which promise to provide empirical-statistical analyses and evidence of consumption patterns in the context of social reconfigurations, simultaneously supply the categories, criteria and indices for the ambitions, repertoires of styles and expressions, and identifications of social subjects. They thereby constitute the social subjects of their investigations in terms of these categories, criteria and registers (see Krige 2009: 3).

This circularity certainly applies to the results of the 'Black Diamond' surveys. Investigation into and debate on the 'black middle class' have been catalysed by institutes and inquiries since 2005, viz. the University of Cape Town-based Unilever Institute of Strategic Marketing, and TNS Research published as 'Black Diamonds 2007 survey: on the move'. Applying a notion of class to heterogeneous social structures and strata with different and contradictory modes of subject interpellation, social obligations and expectations; and characterising professionals, blue collar workers, civil servants, businessmen, consultants and socially and geographically mobile individuals as 'Black Diamonds', are coinages of advertising, market research and the media attempting to frame black South Africans as consumers (ibid: 6). It was through market and commercial banking sector research plotting the consumption patterns, stylisations and preferences, savings, credit and spending patterns of young black adults, rather than through academic sociology, that recent public (and political) debate regarding the social phenomenon of the middle class was shaped (ibid: 3; see also Krige 2013):

... in the process of describing the consumption patterns of this black middle class, these reports are making strong claims about identity and culture, offering that middle class a language with which it identifies and understands itself and gives expression to its own aspirational or newly 'arrived' class position. (Krige 2009: 3) 
Status-seeking through the valorisation and acquisition of commodities instrumental in marking distinction, is subject to commercial commodity culture which in turn levels distinction. To the extent that the deracialisation of distinction is handed over to consumption and commodity fetishism, rather than to a political project, it gives rise to renewed attempts at social differentiation through the search for niche markets and ever more distinctive products, as demonstrated by retail pioneer Richard Maponya, whose autobiography I cited above. Distinction and levelling thus reinforce each other in and through their circularity.

The replication of this circularity across diverse sites is certainly what drove Georg Simmel to distraction, and for good reason, as we shall see. Despairing about the theorisation of 'value', he writes to Heinrich Rickert on 10 May 1898:

The concept of value seems to me to contain not only the same infinite regress as causality, but, over and above that, a circulus vitiosus, because, if one pursues the connections far enough, one always finds the value of A based on that of B, or that of B only based on that of A. (Simmel in Rammstedt 2003: 32)

Foreseeing 'no end to the difficulties' (ibid.) in remaining within the framework of political economy, Simmel proposes to dissolve the logical circle by differentiating the doubling in the formation of value implied in the accounts of political economy. Political economy establishes an equivalence between values of things in the relation of exchange, rendering them comparable and calculable, and assimilating the social relation involved in the exchange to a relation between things entering the exchange process (see Rammstedt 2003: 33). Erasing all traces of past relations between persons and things, being indifferent to persons and things, to local or specific conditions, to origin or mode of acquisition, money renders the exchange relation impersonal and 'characterless' (Simmel [1900]1978: 216). Money as general equivalent has all values, all meanings, all possibilities - and none. Generalised commodity exchange mediated through money tends to dissolve traces of sacrifice, of desire, and ties of personal dependency and mutual obligation. Therein lies the promise of a negative freedom.

\section{Gifts and commodities interrelated}

Having exposed the recurrent circularities in political economy, Simmel develops a Philosophy of money (1900) at the interface between political economy, economic anthropology and a philosophical-historical anthropology.

Some of Simmel's conceptualisations are of a piece with those of cultural and economic anthropologists emerging from both fieldwork and theorisation, starting with the famous contributions on forms of social exchange epitomised in the gift (see Mauss [1923-1924]1980). In extrapolations from and engagements with forms of social exchange, there has been a tendency to distinguish the incommensurable gift 
correlated with the consolidation of socially constructive forms of exchange, from the commodity associated with socially corrosive forms of equivalent exchange in capitalist market economies. The analysis of the first is attributed to Marcel Mauss ([1923-1924]1980), that of the second to Karl Marx ([1867]1962). The stark contrast drawn between them has tended to preclude investigations of coexisting and interrelated forms of economic and social exchanges.

To be sure, we cannot talk of a generalised gift exchange within a market economy in modern complex societies. The market, based on formally equivalent exchange and depersonalised agencies, does not involve reciprocity. The gift retains a personal inalienability which is absent from commodities; the relation between commodities is mediated through depersonalised money, rendering commodities alienable. A recursive exchange of gifts continuously relating the donor and receiver to each other in unpredictable and non-symmetrical ways is the expression of reciprocity, which has to be renewed or modified with each act of giving, thus keeping a dynamic in motion which is absent from the case of commodity exchange. Yet there is movement between spheres that are considered to be separate and distinct, and held apart and irreducible to one another - converting what is considered formally inconvertible, and relating different systems of value and exchange with one another (see Kopytoff 1986: 88).

Commodities can function as gifts, and enter into a set of exchanges and revaluations, especially when it comes to highlighting the finer social distinctions (Gregory 1982: 167-209; also Miller 1995: 141-161; Rock 2004: 287; Yang 2000: 477-509). While generalised commodity exchange mediated by money annihilates distinct locales, histories, modes, cultures, qualities of objects and persons, and personally distinct aspects of social exchange, it can simultaneously differentiate lifestyles marking individual distinction:

In the sense that commoditization homogenizes value, while the essence of culture is discrimination, excessive commoditization is anti-cultural [...] Culture ensures that some things remain unambiguously singular, it resists the commoditization of others; and it sometimes resingularizes what has been commoditized. (Kopytoff 1986: 73)

Such resingularisation of what has been commoditised can be effected through prohibition, sanction, taboo, sacralisation and codes of conduct (written and unwritten), or through withdrawing things from commodity circulation, marking them as unique by attaching them to [the memory of] a particular person, etc.

More recent anthropological writings in the tradition of Mauss are drawing attention to the dialectics between the levelling function of money, and the differentiating functions of culture. Far from remaining inert as a superseded 'archaic' form of exchange, practices related to modes of gift-giving are proliferating. In drawing out 
'What Mauss did not say', Maurice Godelier (2004: 7-8) accords these practices a growing significance:

... [in] Western capitalist societies with their widening gulf between the economy and society, [there are] growing appeals for gifts, for generosity to plug the gaps, the tears in the social fabric. Gift giving is once again becoming a social necessity wherever the economy excludes millions of people, at a time when an earned income has become the general condition of one's material and social existence, where family and community solidarity have shrunk or broken down altogether, and where the individual is isolated within the society by society. Exclusion from the economy quite simply means potential exclusion from society as a whole.

The picture drawn by Godelier could be seen to characterise aspects of the social divides in South Africa, and the gap between formal and informal economies in particular. It provides an important context to the formation of a new class element, some of whose members find themselves in complex situations with often contradictory demands, straddling professional fields of operation governed by policies and contracts, more or less formally regulated financial transactions and business connections; economies of affect (support, communication and provisioning expected on the part of extended family networks or other structurally defined groups); and moral economies (specific 'giving back' protocols to compensate for negative impacts upon disadvantaged relatives and members of communities of origin). While their professional interactions are characterised by the forms and terms of the market economy, they are simultaneously intertwined with different circuits. Pressures in negotiating the corresponding diverse registers would account for the split between a proletarian identification and their own social and economic mobility.

The mutual dependence of these two broadly characterised affiliations produces distinct forms of social exchange. Disengagement from community of origin support is reportedly being felt as an anxiety-inducing relational minefield for new middleclass actors (Stauffer 2009: 12). Their 'poorer cousins', in turn, invoke moral economy repertoires to induce their upwardly mobile kin to show certain giving and sharing gestures. Each group is 'exerting negotiating power over the other so as to exact a "just prize" for reciprocal exchanges' (ibid: 31 ).

The bond of a personal debt to their respective communities of origin, and their own ambiguous and ambivalent relationship to the latter, impel members of the new social stratum to donate their time, materials and expertise in rendering social assistance at a level of 20 per cent higher than their white fellow-citizens - 'from providing intermittent emergency or ongoing financial support, start-up funds, volunteering to do HIV or family care, to involving themselves in various forms of upliftment', mostly in relation to extended family members (ibid: 4). 
The study cited here clearly shows the interrelation of a generalised commodity exchange within a market economy, with non-equivalent, a-symmetrical exchanges in social solidarity. In this case, it is the non-equivalent relation of an inalienable personal debt brought to bear on 'the [impersonal] services of money' (Simmel [1900]1978:215) that motivates gestures such as providing non-repayable loans, seed capital, rewards for personal achievement and community 'upliftment', in the course of which a personal bond would be maintained (even honoured and strengthened) through being socially embedded, albeit on unequal terms.

However appealing this more qualified picture of social mobility may be in mitigating the moral opprobrium raised by practices of conspicuous consumption and corruption scandalising the public in daily and weekly news reports, there is no justification for political romanticism here: '... sanctions that enforce norms of generosity are not necessarily egalitarian in their effects' (Ferguson 2006: 72). ${ }^{6}$ The impulse to 'give back' is not simply the morally redeeming feature mitigating or cancelling out 'immoral' personal enrichment. Or, less morally charged, it is not a matter, as pointed out earlier, of an absolute opposition between the commodity and impersonal, equivalent exchange mediated by money in the capitalist economy on the one hand, and non-equivalent exchange mediated (inter-)personally through mutual recognition, on the other. There is nothing inherent in non-equivalent exchanges that would automatically insulate them from complicity in entrenching social inequalities, corruption and conspicuous consumption - in fact, in some of its modes, what appears as gift exchange could be seen to harbour precisely those possibilities.

Ambivalence is raised in the earliest analyses of gift-giving. This pertains, for instance, to the case in which the gift is so highly doted that it cannot possibly be reciprocated. In that case, the gift elevates the donor and humiliates the recipient who thereby becomes indebted. For the indebted recipient to regain his/her status and dignity, s/he would have to return the initial 'gift' by providing a 'gift' of greater value, thus entering into a spiral of debt and expenditure engulfing ever-widening social networks in 'tournaments of value' (Godelier 2004: 13).

'Tournaments of value', described as complex periodic events culturally removed from the routines of economic life, yet consequential for the understandings and operationalities of power and value in ordinary life, have conceptually been pinned to the kula system (Appadurai 1986: 21). Yet, to the extent that their analysts acknowledge the difficulty of separating gift and commodity exchange even within this culturally specific paradigm, 'tournaments of value' have gained some salience in broader investigations of transfers and transmutations of values between different logics of exchange. In this broader sense, 'tournaments of value' are, in some instructive respects, not absolutely separate and distinct from, or averse and immune to, the spirals of competition describing the logics and logistics of capital 
accumulation and valorisation. Competition involves a struggle against an opponent, imagined or real, who should not be underestimated. For while the figure of the opponent is pivotal for the attainment of the value aspired to, it is disavowed in the aim - the attainment of the valued prize - which is posited independently of the antagonism that defines competition, thus allowing the aim subjectively aspired to, to merge with the end result objectively attained, in ever-widening supra-individual circuits (Simmel I [1903]1995: 224). These circuits become socially formative and societally definitive as competitiveness, understood as a form of aim-directed agonistic struggle entailing mimetic desire, enjoining the agonistes to aspire to the aim in assimilating themselves to it, measuring themselves and each other in relation to it, and competitively 'living up to' it (thereby producing the proverbial 'bandwagon' effect of mass consumption [see Duesenberry 1967], or the felt compulsion of 'keeping up with the Jones's' [see McCormick 1983]).

\section{Commercial and moral value in public contest}

The paradoxical effects of conspicuous consumption in marking social distinction and status while generating the socio-cultural logic for mass consumption, appear combined in political patronage awarding gifts, offices and contracts, and social patronage engaging in ceremonies, gift- or alms-giving, and protection, so as to secure loyalty to politically leading figures, parties or status groups. The lid on this troublesome mix is lifted in the scandalising statements of businessman Kenny Kunene polemically inveighing against the 'struggle asceticism' evinced in the words (but not in the deeds) of his trade union antagonist Zwelenzima Vavi (see Kunene 2011).

The ambiguous examples of giving mentioned here underscore the limits of the gift, in moving towards undermining its very definition. A gift must not return to its point of departure. In other words, it must not be exhausted by the process of exchange. Instead, it must interrupt and dissociate the circles of gift and countergift, gift and debt, gift and loan, gift and credit: 'For there to be a gift it is necessary $[\ldots]$ that the donee not give back, amortize, reimburse, acquit himself, enter into a contract, and that he never have contracted a debt' (Derrida [1991]1992: 12, 7). Socially expected or regulated acts of giving are not pure gifts given in generosity. They become bound, obligatory and obliging, by moral understandings, religion, political interest or law (ibid: 137).

Indebtedness and expressions of gratitude highlighting unequal relations form weak links in gift exchange, potentially distorting the relationship between giver and recipient, generosity and obligation. They may prevent recipients from becoming donors in their turn, enmeshing them in interminable obligations and ambiguities between charity, favours, appeasement and patronage instead. They may entrench 
corruption as giving of 'bad gifts', constituting a 'bad reciprocity' (Ricoeur 2005: $229,231,241)$.

Rather than marking a passage from moral economy through racially coded and restricted economy, to the 'free market' publicly expressed in unfettered conspicuous consumption, I have tried to indicate the simultaneous operation and mutual imbrication of moral economy, gift giving and generalised commodity exchange implicated in a reciprocity that can turn 'bad' (Ricoeur 2006: 241), as it plays itself out between circuits of conspicuous consumption, spectacular acquisition and accumulation, social giving, indebtedness and abject poverty. In this society of the spectacle (of a special kind), practices of conspicuous consumption and their ritualistic, moralistic condemnation do not pose a contradiction in absolute terms, but form part of the same tournament of value - where commercial and moral value enter into a mutually reinforcing public contest with each other, gathering momentum as they jockey for political effect.

This dynamic may give some credibility to the call for limiting the equivalential logic of monetarism through 'blocking exchanges', rendering distinct particular spheres of social interaction and hedging commodification and monetarisation operating across all spheres, rather than to assertions of moral one-upmanship. ${ }^{7}$

\section{Notes}

1 Kunene addressing Vavi: 'You say that my so-called R700 000 party is a "corruption of morality" and that I'm "spitting in the face of the poor". [...] I want to correct your misapprehension that my party cost R700 000. It cost more' (Kunene 2011).

2 Understandings of 'class' differ widely between French Restoration historiography, Marxist theory, Weberian economic history and anthropology, structural Marxism, ANC and SACP programmatics, South African 'social history' scholarship, and, more recently, Bourdieusian directions in sociology inflecting current analyses of 'class in Soweto' and other South African townships (see Seekings 2008). Considering the plurality of conceptual frameworks and their respective political-ideological commitments, I will use this term descriptively, provisionally and cautiously, unless otherwise specified.

3 Most influential in this regard were the SA Communist Party's 1962 'Road to South African Freedom' programme, and the ANC's 1969 Morogoro Conference.

4 For Leo Kuper (1965), the 'African bourgeoisie' comprised black professionals, traders, and senior government and municipal clerks. He explains his understanding of 'class' at the outset - as 'occupational strata':

Bourgeoisie may seem a pompous word for the African professionals, traders, and senior government and municipal clerks who are the subjects of this study. It may also carry the quite misleading implication that there is a well-defined class structure in the African communities of South Africa, consisting of a bourgeoisie and a proletariat, and that by some mysterious process of enclosure, the bourgeoisie comprises all persons following the above occupations and no others. Nothing so 
definite, rigid or classificatory is here intended. ... I apply it specifically to the 'upper' occupational strata of African society. (Kuper 1965: ix)

5 See, e.g., Sonja Narunsky-Laden (2009), who shows how the association of deregulated consumption and emancipation finds its expression in the 1930s in the tabloid press targeting black South Africans with middle-class aspirations.

6 James Ferguson is here citing Moore (1986).

7 See Michael Walzer's stipulation of 'blocked exchanges' (referenced to Arthur Orkin's Equality and efficiency), drawing a line between the sphere of money and the domain of rights, and locating the latter outside of the cash nexus, in the service of a regime of complex equality', where people would be prevented from defining themselves in terms of 'their access to all that money can buy' (Walzer 1983: 100, 105, 107).

\section{References}

African National Congress (ANC). 1998. The state, property relations and social transformation. Discussion paper towards the Alliance Summit. Umrabulo 5, Third Quarter. http://amadlandawonye.wikispaces.com/1998,+ANC,+State,+Property+Relat ions,+Social+Transformation (accessed 14 November 2013).

ANC Youth League (ANCYL). 2009. Political education manual: the national democratic revolution. http://www.ancyl.org.za/docs/political/2009/NDR\%20Presentationb.pdf (accessed 13 November 2013).

Appadurai, A. 1986. Introduction: commodities and the politics of value. In The social life of things: commodities in cultural perspective, ed. A. Appadurai, 3-63. Cambridge: Cambridge University Press.

Bezuidenhout, A., C. Bishoff, S. Buhlungu and K. Lewins. 2008. Tracking progress on the implementation and impact of the Employment Equity Act since its inception. Research commissioned by the Department of Labour, South Africa.

Cantó i Milà, N. 2003. Von der 'Psychologie' zur 'Philosophie' des Geldes. In Georg Simmels Philosophie des Geldes: Aufsätze und Materialien, ed. O. Rammstedt with C. Papilloud, N. Cantó i Milà and C. Rol, 191-214. Frankfurt a.M.: Suhrkamp Verlag.

Charles, K.K., E. Hurst and N. Roussanov. 2007. Conspicuous consumption and race. http://faculty.chicagobooth.edu/erik.hurst/research/race_consumption_qje_ submission.pdf (accessed 12 November 2013).

Derrida, J. 1992. Given time: 1. counterfeit money (1991). Trans. P. Kamuf. Chicago and London: University of Chicago Press.

Duesenberry, J.S. 1967. Income, savings and the theory of consumer behavior. New York: Oxford University Press.

Ferguson, J. 2006. Global shadows: Africa in the neoliberal world order. Durham and London: Duke University Press.

Frazier, F. 1957. The black bourgeoisie: the rise of a new middle class. New York: The Free Press.

Gilroy, P. 2010. Darker than blue: on the moral economies of Black Atlantic culture. Cambridge: Harvard University Press. 
Godelier, M. 2004. What Mauss did not say: things you give, things you sell, and things that must be kept. In Values and valuables: from the sacred to the symbolic, ed. C. Werner and D. Bell, 3-20. Walnut Creek, Lanham and Oxford: Altamira Press.

Gregory, C. 1982. Gifts and commodities. London: Academic Press.

Hlengani, T. 2007. Soweto's investment boom. Financial Mail, 27 April. http://secure. financialmail.co.za/07/0427/controversy.htm (accessed 14 April 2009).

IOL News. 2010, February 20. Sadtu supports call for lifestyle audit. http:/www.iol.co.za/ index.php?art_id=nw20100220164936221C411362 (accessed 13 November 2013).

Kaus, W. 2010. Conspicuous consumption and race: evidence from South Africa. Papers on Economics and Evolution, Evolutionary Economics Group, paper no. 3. Jena: Max Planck Institute.

Kopytoff, I. 1986. The cultural biography of things: commoditization as process. In The social life of things: commodities in cultural perspective, ed. A. Appadurai, 64-91. New York: Cambridge University Press.

Krige, D. 2009. The power of and problems with marketing research: history, social class, and the so-called black diamonds. Paper presented to the Comprehending Class Conference, UJ/Wits, 23-26 June. Proceedings Volume I.

Krige, D. 2013. 'Letting money work for us': self-organization and financialisation from below in an all-male savings club in Soweto. Paper presented to the Conference Human Economy: Economy and Democracy, University of Pretoria, 22-24 August.

Kunene, K. 2011. I'll spend what I like. Open letter. Times Live, 29 October. http://www. timeslive.co.za/opinion/article733038.ece/Ill-spend-what-I-like (accessed 13 November 2013).

Kuper, L. 1965. An African bourgeoisie: race, class and politics in South Africa. New Haven: Yale University Press.

Leibbrandt, M., I. Woolard, A. Finn and J. Argent. 2010. Trends in South African income distribution and poverty since the fall of apartheid. OECD Social, Employment and Migration Working Papers, No. 101.

Mager, A. 2007. Redefining the shebeen: the illicit liquor trade in South Africa, c. 19501983. In Economies of representation, 1790-2000: colonialism and commerce, ed. H. Gilbert and L. Dale, 83-92. Aldershot: Ashgate.

Maponya, R. 2010. Acceptance speech on the conferring of an Honorary Doctorate at the University of Johannesburg, 29 September. http://www.uj.ac.za/EN/Newsroom/News/ Pages/AcceptanceSpeechbyDrRichardMaponya.aspx (accessed 13 November 2013).

Marx, K. 1962. Das Kapital: Kritik der politischen Ökonomie, Erster Band (1867). MarxEngels Werke (MEW), Band 23. Berlin, DDR: Dietz Verlag.

Mauss, M. 1980 (1923-1924). The gift: forms and functions of exchange in archaic societies. London: Routledge.

Mbeki, T. 2006. Nelson Mandela Memorial Lecture, University of the Witwatersrand, July 29. www.dfa.gov.za/docs/speeches/2006/mbeki0729.htm (accessed 10 January 2011).

McCormick, K. 1983. Duesenberry and Veblen: the demonstration effect revisited. Journal of Economic Issues 17(4): 1125-1129.

Miller, D. 1995. Consumption and commodities. Annual Review of Anthropology 24: 141161. 
Moore, S.F. 1986. Social facts and fabrications: 'customary' law on Kilimanjaro, 18801980. New York: Cambridge University Press.

Narunsky-Laden, S. 2009. From the African bourgeoisie to the black middle classes: class complexities in contemporary South Africa. Paper presented to the Comprehending Class Conference, UJ/Wits, Johannesburg, 23-26 June. Proceedings Volume II.

Nzimande, B. 2006. The class question as the 'fault-line' in consolidating the national democratic revolution. Umsebenzi 5(57). http://www.sacp.org.za/pubs/umsebenzi/2006/ no57.html (accessed 13 November 2013).

Plaut, M. and P. Holden. 2012. Who rules South Africa? Pulling the strings in the battle for power. Johannesburg and Cape Town: Jonathan Ball.

Posel, D. 2010. Races to consume: revisiting South Africa's history of race, consumption, and the struggle for freedom. Ethnic and Racial Studies 33(2): 157-175.

Rammstedt, O. 2003. Wert, Geld und Individualität. In Georg Simmels Philosophie des Geldes: Aufsätze und Materialien, ed. O. Rammstedt with C. Papilloud, N. Cantó i Milà and C. Rol, 27-41. Frankfurt a.M.: Suhrkamp Verlag.

Ricoeur, P. 2005. The course of recognition. Cambridge (MA) and London: Harvard University Press.

Rock, M. 2004. Numbered days, valued lives: statistics, shopping, pharmacy and the commodification of people. In Values and valuables: from the sacred to the symbolic, ed. C. Werner and D. Bell, 282-306. Walnut Creek, Lanham and Oxford: Altamira Press.

Seekings, J. 2008. The rise and fall of the Weberian analysis of class in South Africa between 1949 and the early 1970s. Centre for Social Science Research, CSSR Working Paper No. 239.

Seekings, J. 2011. Poverty and inequality in South Africa, 1994-2007. In After apartheid: reinventing South Africa? ed. I.S. Shapiro and K.T. Tebeau, 21-51. Charlottesville: University of Virginia Press.

Seekings, J. and N. Nattrass. 2006. Class, race and inequality in South Africa. Pietermaritzburg: University of KwaZulu-Natal Press.

Simmel, G. 1989. Philosophie des Geldes (1900), ed. D. Frisby and K.C. Köhnke. (Gesamtausgabe Bd. 6). Frankfurt a.M.: Suhrkamp Verlag.

Simmel, G. 1995. Soziologie der Konkurrenz (1903). In Aufsätze und Abhandlungen 1901-1908, Bd I, ed. R. Kramme, A. Rammstedt and O. Rammstedt, 221-245 (Gesamtausgabe, Bd. 7). Frankfurt a.M.: Suhrkamp Verlag.

Simmel, G. 2010. A chapter in the philosophy of value (1900). In Georg Simmel: Englischsprachige Veröffentlichungen, 1893-1910, ed. D.P. Frisby, 141-166 (Gesamtausgabe, Bd. 18). Frankfurt a.M.: Suhrkamp. (This article forms part of the first chapter ('Wert und Geld'), of Philosophie des Geldes [1900].)

Stauffer, C. 2009. From the African bourgeoisie to the black middle classes: class complexities in contemporary South Africa. Paper presented to the Comprehending Class Conference, UJ/Wits, 23-26 June. Proceedings Volume II.

Veblen, T. 1915. Theory of the leisure class: an economic study of institutions (1899). New York: Macmillan. 
Walzer, M. 1983. Spheres of justice: a defence of pluralism and equality. New York: Basic Books.

Weber, M. 1978. Economy and society: an outline of interpretive sociology (1922). Berkeley and Los Angeles: University of California Press.

Wilson, M. and A. Mafeje. 1963. Langa: a study of social groups in an African township. Cape Town: Oxford University Press.

Yang, M. 2000. Putting global capitalism in its place: economic hybridity, Bataille, and ritual expenditure. Current Anthropology 41(4): 477-509. 